\title{
Sediments and the "System": from site-specific to regional-scale research
}

\author{
"A story of joy in researching dirt"
}

\author{
Wim Salomons • Ulrich Förstner
}

Received: 12 October 2010 / Accepted: 13 October 2010 / Published online: 4 November 2010

(C) The Author(s) 2010. This article is published with open access at Springerlink.com

\section{Sediments and contaminants}

Sediments are part of the erosion-sedimentation cycle; material from the terrestrial environment is turned into rock, boulders and sand-, silt- and clay-sized particles through weathering, which are subsequently transported by wind and water erosion through rivers, and ultimately end up in the ocean. During transport, temporary deposition takes place in the river beds, flood plains, wetlands, deltas and estuaries (Fig. 1). In these depositional areas, sediment is an integral part of the ecosystem.

Geology deals with research in both ancient and recent deposits of sediments. More than 14,000 books listed by Amazon under the search term "sediments" reflect the current education and research effort on this topic, which started more than 200 years ago (Hutton 1788).

The more recent aspects of sediments and sedimentology are covered by our journal; the impact of humans on the

For both of us, it has been a struggle on how to write a kind of official "Farewell address" to our colleagues. After all, we do it only once in our lifetime. The result is twofold; we will have one editorial with a broad and short (admittedly very biased) history and outlook of our experience, and a second, more scientific editorial, which covers the first 10 years of our Journal of Soils and Sediments.

\section{W. Salomons $(\square)$}

Kromme Elleboog 21,

9751 RB Haren (Gn), The Netherlands

e-mail: wim.salomons@home.nl

\section{U. Förstner $(\square)$}

Institute of Environmental Technology and Energy Economics,

Hamburg University of Technology (TUHH),

Eissendorfer Str. 40,

21071 Hamburg, Germany

e-mail: u.foerstner@tu-harburg.de quality and quantity of sediments in aquatic systems. Here, the survey of Amazon, using "sediment pollution", shows about 1,200 books which are still for sale. On the other hand, searching in Google Scholar really shows how active our field is: for "sediment", there are 1,460,000 hits and for "sediment pollution", the number is 583,000 . These simple crude statistics suggest that one third of all sediment research deals with pollution aspects.

Looking back, research on sediment pollution reflects the typical sequence of academic research through research for legislation to implementation (Fig. 2). In the first part of the twentieth century, sediment pollution research was in the realms of classic geochemistry (Goldschmidt 1954). Important applied areas included research for ore prospecting and micronutrients in soil science. In fact, in The Netherlands, elevated levels of heavy metals in wetlands from the Rhine-Meuse delta were detected during soil surveys in order to determine their potential for agricultural use after embankment.

Human fatalities in Japan, linked to sediments and soils (Hagino and Yoshioka 1961; Fujiki 1972), caused worldwide concern. These and other incidents really put contaminated sediments on the political agenda as a societal issue. Hence, since the 1970s sediment research became policy driven with ample funding to determine its extent and potential impact (i.e. "Coming to Grips" in Fig. 2).

Subsequently, several techniques were developed to determine and predict such impacts. These included geochemical modelling of aquatic systems (e.g. Garrels and Christ 1965; Stumm and Morgan 1971) and the biogeochemical processes in the deposited sediments (e.g. Berner 1971) and the introduction of bio-assays (e.g. Sunda and Guillard 1976). In addition, comparisons were made with contaminant levels to those found in unpolluted sediments, and the mode of occurrence of contaminants in sediments was studied to infer their reactivity (e.g. Förstner and Salomons 1980). 


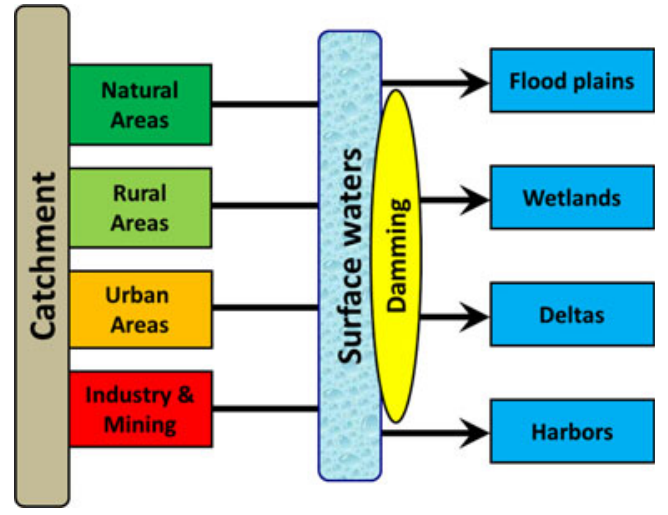

Fig. 1 The flow of water, sediment and contaminants from land, through rivers to impacted areas downstream (Catchment-Coast Continuum)

Early research showed that the activity of organisms in sediments, or within lakes, cannot be neglected in the study of sediment-water interactions (e.g. Jernelov 1970; Renfro 1973; Andersson et al. 1978). These early pioneering studies were a prelude to the current holistic ecosystem approaches (Anonymous 2005a). Similarly, the impact of human activities on the global cycling of elements was recognised (Garrels et al. 1975). These global aspects became part of the comprehensive LOICZ (Crossland et al. 2005) and BAHC (Kabat et al. 2004) projects of the international IGBP program (Steffen et al. 2004). Due to this scientific research, the results were gradually put into legislation. In 1983, the US Army Corps of Engineers published a first manual on dredging and dredged material disposal (Anonymous 1983). The implementation of legislation resulted in applied research on environmental safe relocation and containment of dredged material that continues until today (Anonymous 2005b).

The overview of European legislation relating to environmental and related fields, in Fig. 3, shows clearly the shift from conserving single species (e.g. the Bird Directive) and human health (e.g. the Bathing Water Directive) to ecosystem-based approaches (e.g. the Water Framework and Marine Strategy Directives). Authorities, like the Port of Rotterdam, quickly followed suite, and shifted their approach for dredging management (Nijssen 1988; Vellinga and Eisma 2005).

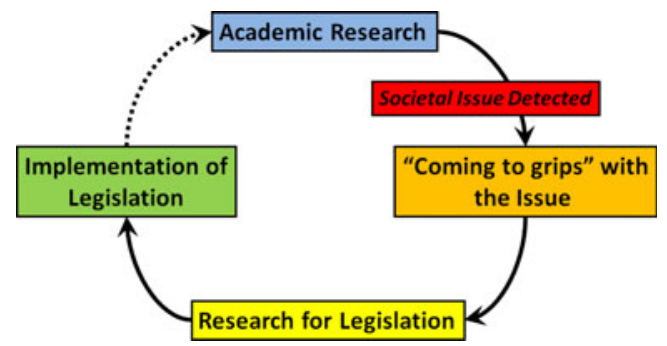

Fig. 2 The academic research to implementation cycle, consisting of i. Academic research, ii Policy driven research ("coming to grips"), iii Research for legislation, iv Research during implementation
The past decades have shown large reductions in concentrations of "classical" contaminants in sediments in most Western countries (Vink et al. 1999). Despite the large reductions in inputs from point sources, there are still elevated levels of contaminants in fluvial sediments. The inputs are now mainly due to diffuse sources and nonpoint pollution sites within the catchment (Gandrass and Salomons 2001). This "Legacy of the Past" issue is relevant to all industrialized and agriculture intensive river catchments (Stigliani and Salomons 1993). Changing conditions (Salomons and Stigliani 1995), in particular erosion, cause a release of contaminants in the catchment.

With the implementation of legislation, reduction in point sources and the development of feasible solutions for the relocation of contaminated sediments, most of the research that dealt with "Coming to Grips" with contaminated sediments at the site-specific level enters the academic research agenda again (see Fig. 2).

\section{Sediments as part of the system}

It is evident that over the past decade, the paradigm of our research has shifted, both from the science and the policy viewpoint. A recent survey of close to 100 catchments by LOICZ showed that damming and urbanization are currently the major drivers for change in river catchments, with industrialization ("classical" pollution) having a much lower ranking (Salomons et al. 2005). Sediments are not only sitespecific issues, but it is now recognised that they are part of, and interlinked with, the "system". The "system" being global is addressed in science through the approaches of IGBP (natural sciences) and IHDP (socio-economics and human sciences) or through legislation that addresses the river basin scale like the European Water Framework Directive. Sediment research at the global level is facilitated by the "International Sediment Initiative" of UNESCO. This new paradigm can also be found in the results of EU projects such as SEDNET (Salomons and Brils 2004) and RISKBASE (Brils and Harris 2009) and increasingly in the articles published in JSS. Comparing key reports of regulatory agencies like the US Army Corps of Engineers (Anonymous 1983 versus Anonymous 2002) also shows this change in paradigm. In addition, it is being recognised that natural and anthropogenic impacts in the spatial parts of the basin (brook, stream, river, estuary) exhibit differences in time response varying between days and centuries (Meybeck 2002).

This new paradigm includes not only the quantitative and the qualitative aspects of sediments but also societal aspects, such as the use and non-use values of sediments as a resource (Pearce and Turner 1990; Brouwer et al. 2004). The DPSIR framework of analysis (Anonymous 1993) and the concept of Ecosystem Services (Turner and Daily 2008; 


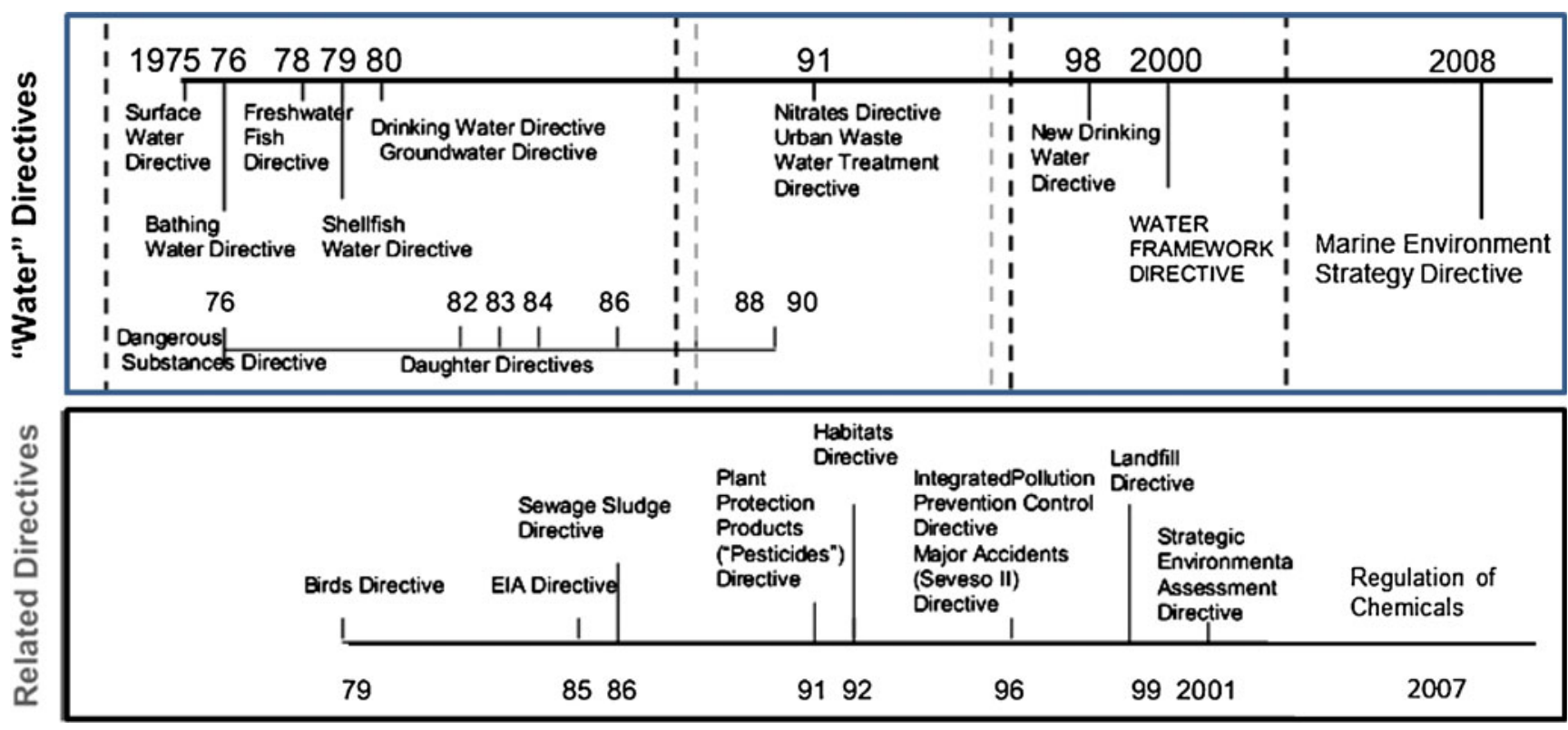

Fig. 3 The various legislation implemented by the EU, which shows the movement from protection of species and point sources to a holistic approach like the Water Framework Directive (WFD) and the related Marine Environment Strategy Directive (modified from Ledoux et al. 2005)

Fisher et al. 2009) have been very useful to integrate the socio-economic and natural sciences for the management of our natural resources.

Acknowledgements We have a large number of colleagues to thank for their guidance, support and teamwork. First the ones on whose shoulders we stood: Ane Jan de Groot, Wim Mook and German Muller. Secondly, our earlier colleagues from the pioneering phase of the 1970s and 1980s: Rod Allan, Barry Hart, Luiz Drude de Lacerda, Bill Stigliani and Richard Thomas. Thirdly, the colleagues from the past decades: Kerry Turner, Michel Meybeck, Hartwig Kremer, Jos Brils, Tiedo Vellinga, Jan Vermaat and many others. We also carried out much applied research for agencies and industry. In particular, the cooperation with the Port of Rotterdam, Ok Tedi Mining Co and Bougainville Copper shaped our efforts in obtaining the "integrated picture". The journal in which this editorial is published would not have been possible without the energy of Almut Heinrich. But let us not forget Uta and Lucia (and the children) who had to endure the hectic periods of our research.

Open Access This article is distributed under the terms of the Creative Commons Attribution Noncommercial License which permits any noncommercial use, distribution, and reproduction in any medium, provided the original author(s) and source are credited.

\section{References}

Andersson G, Berggren H, Cronberg G, Gelin C (1978) Effects of planktivorous and benthivorous fish on organisms and water chemistry in eutrophic lakes. Hydrobiologia 59:9-15

Anonymous (1983) US Army Corps of Engineers Engineer Manual No. 1110-2-5025. Engineering and design-dredging and dredged material disposal

Anonymous (1993) Organisation for Economic Co-operation and Development (OECD) core set of indicators for environmental performance reviews. OECD Environment Monographs No. 83, Paris. http://www.oecd.org/dataoecd/32/20/31558547.pdf

Anonymous (2002) US Army Corps of Engineers: IWR Report 02PS-2. Regional Sediment Management

Anonymous (2005a) Millennium ecosystem assessment. http://www. maweb.org/en/Index.aspx

Anonymous (2005b) Contaminated sediment remediation-guidance for hazardous waste sites. US EPA: EPA-540-R-05-012. Office of Solid Waste and Emergency Response, Washington DC

Berner RA (1971) Principles of chemical sedimentology. McGrawHill, New York

Brils J, Harris B (eds) (2009) Towards risk-based management or European river basins: key-findings and recommendations of the RISKBASE project, EC FP6 reference GOCE 036938, December 2009, Utrecht, The Netherlands. http://www.riskbase.info/

Brouwer R, Georgiou S, Turner K (2004) Integrated assessment and sustainable wetland management: a review of concepts and methods. J Integ Assess 4(3):171-183

Crossland CJ, Kremer HH, Lindeboom HJ, Marshall Crossland JJ, Le Tissier MDA (2005) Coastal fluxes in the anthropocene. Springer, Berlin

Fisher B, Turner RK, Morling P (2009) Defining and classifying ecosystem services for decision making. Ecol Econ 68:643659

Förstner U, Salomons W (1980) Trace metal analysis on polluted sediments. Part I. Assessment of sources and intensities. Env Technol Lett 1:494-505

Fujiki (1972) The transitional conditions of Minimata Bay and the neighbouring sea polluted by factory waste water containing mercury. 6th Int. Conf. Water Pollut. Res. Paper No. 12

Gandrass J, Salomons W (2001) Dredged material in the Port of Rotterdam-Interface between the Rhine catchment and North Sea. GKSS Report, p 342. http://coast.gkss.de/aos/dredged material/

Garrels RM, Christ CL (1965) Solutions, minerals and equilibria. Harper \& Row, New York

Garrels RM, MacKenzie FT, Hunt C (1975) Chemical cycles and the global environment-assessing human influences. William Kaufmann, California

Goldschmidt VM (1954) Geochemistry. Clarendon, Oxford 
Hagino N, Yoshioka K (1961) A study on the cause of the itai-itai disease. J Jpn Orthop Assoc 35:812

Hutton $J$ (1788) Theory of the earth; or an investigation of the laws observable in the composition, dissolution, and restoration of land upon the globe. Trans R Soc Edinb 1(Part 2):209304

Jernelov A (1970) Release of methyl mercury from sediments containing inorganic mercury at different depths. J Limnol Oceanogr 15:958-960

Kabat P, Claussen M, Dirmeyer PA, Gash JHC, Bravo de Guenni L, Meybeck M, Pielke R, Vörösmarty CJ, Hutjes RWA, Lütkemeier $\mathrm{S}$ (eds) (2004) Vegetation, water, humans and the climate. Springer, Heidelberg

Ledoux L, Vermaat JE, Bouwer LM, Salomons W, Turner RK (2005) ELOISE research and the implementation of EU policy in the coastal zone. In: Vermaat J, Bouwer L, Turner K, Salomons W (eds) Managing European coasts-past, present and future. Springer, Berlin, pp 1-20

Meybeck M (2002) Riverine quality at the anthropocene: propositions for global space and time analysis, illustrated by the Seine river. Aquat Sci 64:376-393

Nijssen JPJ (1988) Rotterdam dredged material: approach to handling. In: Salomons W, Förstner U (eds) Environmental management of solid waste. Springer, Berlin

Pearce DW, Turner RK (1990) Economics of natural resources and the environment. Harvester Wheatsheaf, UK, 378 pp

Renfro WC (1973) Transfer of Zn-65 from sediments by polychaete worms. Mar Biol 21:305-316
Salomons W, Stigliani W (eds) (1995) Biogeodynamics of pollutants in soils and sediments. Springer, Berlin

Salomons W, Kremer H, Turner RK (2005) The catchment to coast continuum. In: Crossland $\mathrm{CJ}$, Kremer HH, Lindeboom HJ, Marshall Crossland JJ, Le Tissier MDA (eds) Coastal fluxes in the anthropocene. Springer, Berlin, pp 145-200

Salomons W, Brils J (2004) Contaminated sediments in European river basins. EU-Project. EVK1-CT-2001-20002. http://www. sednet.org/

Steffen W, Sanderson RA, Tyson PD, Jäger J, Matson PA, Moore B III, Oldfield F, Richardson K, Schellnhuber HJ, Turner BL, Wasson RJ (2004) Global change and the earth system. Springer, Heidelberg

Stigliani W, Salomons W (1993) Our fathers' toxic sins. New Sci $140: 38-42$

Stumm W, Morgan JJ (1971) Aquatic chemistry. Wiley, New York

Sunda WG, Guillard RRL (1976) The relationship between cupric ion activity and the toxicity of copper to phytoplankton. J Mar Res 34:511-519

Turner RK, Daily GC (2008) The ecosystem services framework and natural capital conservation. Environ Resour Econ 39:25-35

Vellinga T, Eisma M (2005) Management of contaminated dredged material in the port of Rotterdam. In: Vermaat J, Bouwer L, Turner K, Salomons W (eds) Managing European coasts-past, present and future. Springer Publ. Co., Berlin, pp 315-322

Vink RJ, Behrendt H, Salomons W (1999) Development of the heavy metal pollution trends in several European rivers: An analysis of point and diffuse sources. Water Sci Technol 39(12):215-223 